\title{
5
}

\section{Fluvial Sediment Supply and Relative Sea-Level Rise}

\section{Stephen E. Darby, Kwasi Appeaning Addo, Sugata Hazra, Md. Munsur Rahman and Robert J. Nicholls}

\subsection{Introduction}

The world's major deltas are facing a sustainability crisis (Giosan et al. 2014; Anthony et al. 2015). Of the world's 33 largest deltas, 28 are at high risk of being 'drowned' as a result of relative sea-level rise (Syvitski et al. 2009). These changes have profound implications for human habitation of these systems and suggest wide-scale abandonment, or a growing dependency on dykes, artificial drainage and polders. Given deltas' role in food production, the potential consequences for regional and global food security are readily

S. E. Darby $(\square)$

Geography and Environmental Science,

University of Southampton, Southampton, UK

e-mail: S.E.Darby@soton.ac.uk

K. Appeaning Addo

Department of Marine and Fisheries Sciences, Institute

for Environment and Sanitation Studies, University of Ghana, Legon-Accra, Ghana

(C) The Author(s) 2020 
apparent: around 20\% of the land within the large deltas of South and Southeast Asia will likely be lost by 2100 unless protected by dykes (Giosan et al. 2014; Smajgl et al. 2015). The challenge of securing, let alone increasing, food production is further compounded by the enhanced flood risk and waterlogging as well as the problems of saline intrusion that are also associated with sea-level rise. For these reasons there is widespread concern that the current combination of environmental stresses affecting deltas is leading to accelerated rates of relative sea-level rise. Current rates of relative sea-level rise for 46 of the world's major deltas average $6.8 \mathrm{~mm} / \mathrm{yr}$ (Tessler et al. 2018) and these average changes do not capture 'hotspots' of subsidence within these deltas. This delta-specific rate is double that of the global trend of sea-level rise due to climate change, as measured with satellites.

The factors contributing to relative sea-level change in deltas are well understood, at least in a qualitative sense (Syvitski et al. 2009), with the change in delta surface elevation relative to sea-level being derived as the sum of the rates of natural compaction and anthropogenic subsidence, eustatic sea-level change, rate of crustal deformation due to local geodynamics, and the rate of surface aggradation (Fig. 5.1). It is important to understand that deltas naturally sink relative to sea level as a result of the natural compaction of sediments, but anthropogenic activities such as groundwater abstraction or hydrocarbon extraction often also induce accelerated subsidence (Erban et al. 2014; Brown and Nicholls 2015; Minderhoud et al. 2017). This accelerated subsidence is being compounded in many deltas by (the local expression of)

S. Hazra

School of Oceanographic Studies, Jadavpur University, Kolkata, India

M. M. Rahman

Institute of Water and Flood Management,

Bangladesh University of Engineering and Technology,

Dhaka, Bangladesh

R. J. Nicholls

School of Engineering, University of Southampton, Southampton, UK 


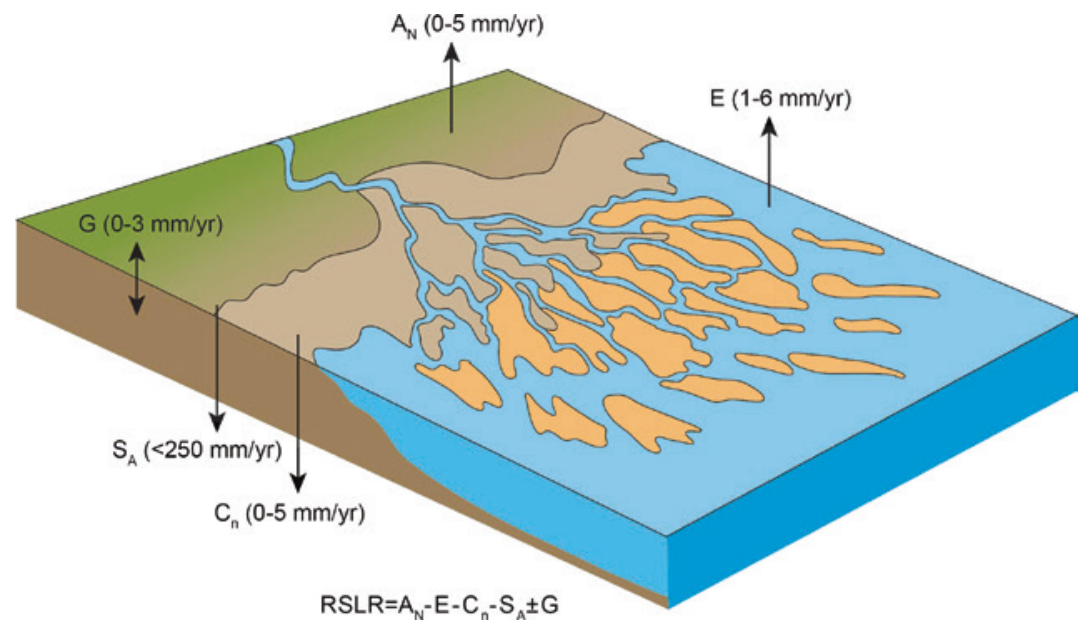

Fig. 5.1 Overview of the factors and processes contributing to relative sea-level rise within deltas. Most of the world's large deltas currently have low rates of natural sediment supply and high rates of eustatic sea-level rise $(E)$ and often higher rates of human-induced subsidence $\left(\mathrm{S}_{\mathrm{A}}\right)$, meaning that significant portions of the world's deltas are at risk of imminent drowning, with sediment accretion $\left(A_{N}\right)$ being the only factor that can offset relative sea-level rise. Note that $C_{n}$ and $G$ denote natural compaction and crustal deformation, respectively

eustatic sea-level rise as a result of anthropogenic warming (Cazenave and Remy 2011). Thus, as human agency drives these trends, high rates of relative sea-level rise in deltas can be considered as an indicator of the Anthropocene.

Importantly, of all the drivers of relative sea-level change, the only factor that can potentially offset rising sea level, and therefore its associated risks, is sediment accretion on the delta surface. This means that it is critically important to understand the processes affecting sediment accretion-the geomorphic dynamics of deltas. In fact surface accretion rates can be understood to be affected primarily by two main factors: (i) the rate of fluvial sediment supply from the catchment upstream (Darby et al. 2016; Dunn et al. 2018; Rahman et al. 2018), and (ii) the capacity of deltas to retain that sediment (Syvitski and Kettner 2011). Yet, both of these dimensions of geomorphic dynamics of deltas are 
susceptible to human modification and human pressures are ubiquitous in many delta environments. This means that many of the world's major deltas may already have reached a major tipping point in which they have been shifted from a quasi-stable Holocene state to what might now be regarded as an Anthropocene (Crutzen and Stoermer 2000) state in which delta dynamics are predominantly controlled by human activity (Tessler et al. 2015).

In order to understand the drivers underlying this postulated transition from Holocene to Anthropocene deltas, alongside the potential social-ecological impacts of such a transition (Fig. 5.2), it is possible to consider the major past trends in fluvial sediment supply on major deltas. Specifically, prior studies have highlighted how fluvial sediment delivery is a critical factor in countering relative sea-level rise (Ericson et al. 2006; Syvitski et al. 2009), but that rates of sediment supply to deltas have typically declined significantly in the last few centuries as a result of catchment land use change reducing sediment yield and sediment trapping behind constructed reservoirs (Milliman and Syvitski 1992;

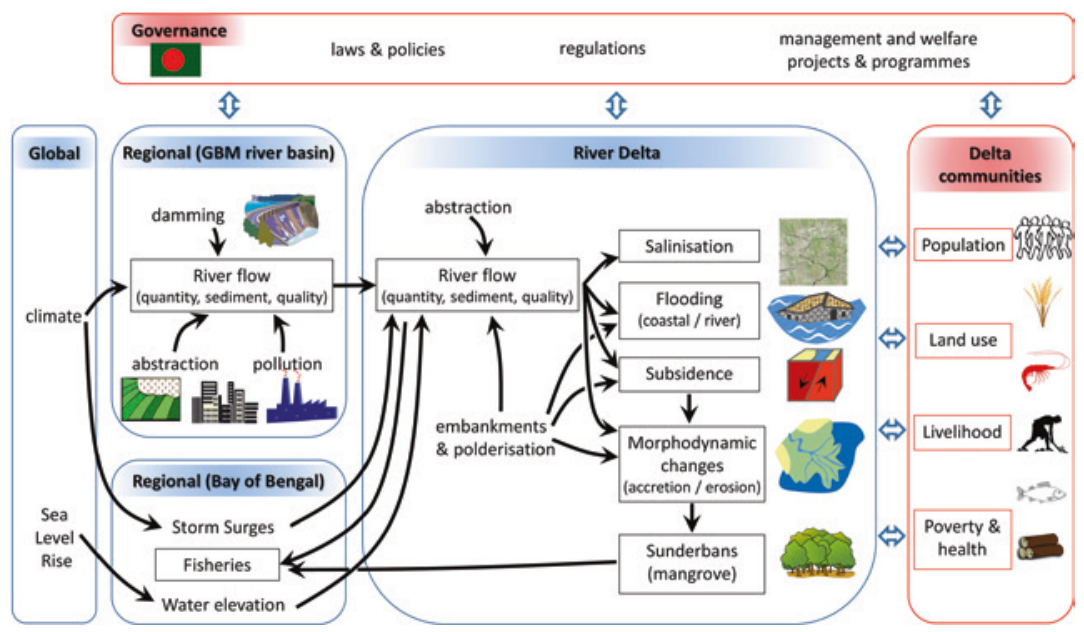

Fig. 5.2 Drivers of geomorphological change for deltas in the Anthropocene (Reprinted with permission from Nicholls et al. [2016]) 
Darby et al. 2016). Prior to these changes of the last few centuries, many of the world's deltas experienced increased rates of fluvial sediment supply associated with major land use changes driven by the onset and subsequent intensification of agriculture (Milliman et al. 1987). This points to a scenario whereby past changes in sediment flux supplied to deltas have been driven primarily by major and direct human modifications to the feeder catchments upstream of deltas, with climate-driven changes only of secondary importance (Darby et al. 2015). As discussed in this chapter, however, the radical shift in boundary conditions associated with this transition to a new Anthropocene catchment-delta system means that the effect of climate-related changes may become relatively more significant in the future.

\subsection{Objectives and Overview}

The aim of this chapter is to consider present and future sediment delivery and distribution in deltas, as a fundamental control on delta futures and illustrate how these processes have been, and are being, significantly impacted by human activity. It is argued that the extent of human activity is so great that, in many of the world's deltas, it is no longer possible to regard these processes as being 'natural' but rather it is more appropriate to consider deltas as existing in an Anthropocene state. The chapter is structured as follows. Below, in Sect. 5.3 case studies of three deltas are presented to illustrate how their status has been shifted from pre-disturbance Holocene deltas to at-risk deltas of the Anthropocene, largely as a result of the disruption of sediment flux by human activity. In Sect. 5.4 the 'prospects' for the futures of these and other deltas are considered, examining how changing geomorphological processes in the deltas and their catchments might affect their relative sea-level rise in the future and considering how human activity can be modified to promote a more sustainable future for at-risk deltas. 


\subsection{Trends of Fluvial Sediment Supply in Three Deltas}

In this section the evidence base for understanding how geomorphological processes have evolved from the Holocene to the present day and beyond is presented, using the three deltas (described in Chapters 2-4) as case studies. It also examines the extent to which transitions have occurred creating an 'Anthropocene' state related to human disturbance.

\section{The Ganges-Brahmaputra-Meghna Delta}

The Ganges-Brahmaputra-Meghna (GBM) Delta (see Chapter 2, Fig. 2.1) is the second largest in the world by area, and is home to more than 100 million people (Ericson et al. 2006). The delta is fed by two major rivers, the Ganges and Brahmaputra, as well as the Meghna, with the combined catchments draining land in Bangladesh, Bhutan, China, India and Nepal. The delta itself covers the coastal region of much of Bangladesh and part of West Bengal, India, with the delta front extending for some $380 \mathrm{~km}$ (Allison 1998). The GBM Delta is tidally influenced, with the zone of the tidal influence extending up to $100 \mathrm{~km}$ inland. The many people who live in the delta live often in extreme poverty and are highly exposed to natural hazards including tropical cyclones, tidal flooding, and river and coastal erosion.

The catchments feeding the delta are located in a neo-tectonically active basin affected by block faulting and rifting which has led to frequent changes of river course and sediment supply to the delta. During the early sixteenth century, due to the easterly tilt of the basin by block faulting, the main flow of the Ganges shifted eastward and merged with the flow of Brahmaputra and then subsequently with the Meghna (Morgan and McIntire 1959) leaving the southerly flowing distributaries (e.g., Bhagirathi-Hoogly and Gorai) dry except during the monsoon period. Delta progradation, both in the subaerial and subaqueous domains continues presently only in the eastern part of the GBM Delta (i.e., the Meghna estuary) where active accretion is creating new land area (Wilson and Goodbred 2015). In contrast, the western part of the 
delta, especially the Hoogly or Harinbhanga estuary, has effectively been 'abandoned' (Allison et al. 2003) by the Ganges and most of the distributaries of the Ganges have now lost their upstream fresh water sources and have gradually silted up. The most recent and probably the largest direct human intervention in the delta dynamics is associated with the construction of the Farakka Barrage in 1975 (see Chapter 2), which was designed in part to redirect the dry season flow of the Ganges to the otherwise moribund Bhagirathi-Hoogly River system and the city of Kolkata. The barrage, which was built at the apex of the delta, not only initiated sedimentation upstream of the barrage, but it also considerably reduced the sediment supply downstream (Gupta et al. 2012). Field measurements show that there is now strong evidence that the combined sediment flux delivered by these two major river systems is following a declining trend (with a current rate of decline of $\sim 10 \mathrm{Mt} / \mathrm{a}$ ), such that the present fluvial sediment flux is probably about half $(-500$ $\mathrm{Mt} / \mathrm{a})$ of its pre-disturbance value $(-1000 \mathrm{Mt} / \mathrm{a})$ (Rahman et al. 2018).

In the last three decades, the northern part of the Bay of Bengal has recorded a sea-level rise of the order of $8 \mathrm{~mm} / \mathrm{yr}$ (Pethick and Orford 2013). Indeed, two inhabited estuarine islands (Lohachara and Suparibhanga) and New Moore island in the western part of the delta have been completely lost due to a mixture of erosion and submergence (Hazra et al. 2016), reflecting low sediment supply to this part of the GBM Delta. This vulnerability is exacerbated by the GBM Delta's tendency to subsidence resulting from compaction of the deltaic deposits and anthropogenic interventions make the situation crucial to manage the delta in the coming decades. Recent studies (Pethick and Orford 2013; Brown and Nicholls 2015) show a wide range of variation of subsidence, varying from fraction of a millimetre to $45 \mathrm{~mm} / \mathrm{yr}$ locally. Unable to cope with rising sea level and the reduced sediment supply (Rahman et al. 2018) the western part of the delta, in effect now abandoned by the Ganges, has suffered severe land loss to the sea over at least the last 150 years. Between 1792 and 1984, the delta lost $368 \mathrm{~km}^{2}$ in the west while gaining $1346 \mathrm{~km}^{2}$ in the east (i.e., around the Meghna Estuary) (Allison 1998). This wide range of variation of land change within the delta itself makes it necessary to adopt an adaptive approach to face the challenges of climate change. Thus the eastern part of the 
delta still maintains a supply of fluvial sediment that could enable active sediment management and restoration (see Sect. 5.4), whereas the western part is sediment starved today. Here, extensive areas of the delta will fall below mean sea level, requiring either abandonment or protective sea dykes.

\section{The Mahanadi Delta}

The Mahanadi Delta (Fig. 5.3), located in the state of Odisha on the east coast of India, is an arcuate shaped wave-dominated delta formed under a micro-tidal regime (Kumar and Bhattacharya 2003). A network of three major rivers: the Mahanadi (and its distributaries, the Devi, Daya, Bhargavi, Kushbhandra and Parchi) and the adjoining Brahmani

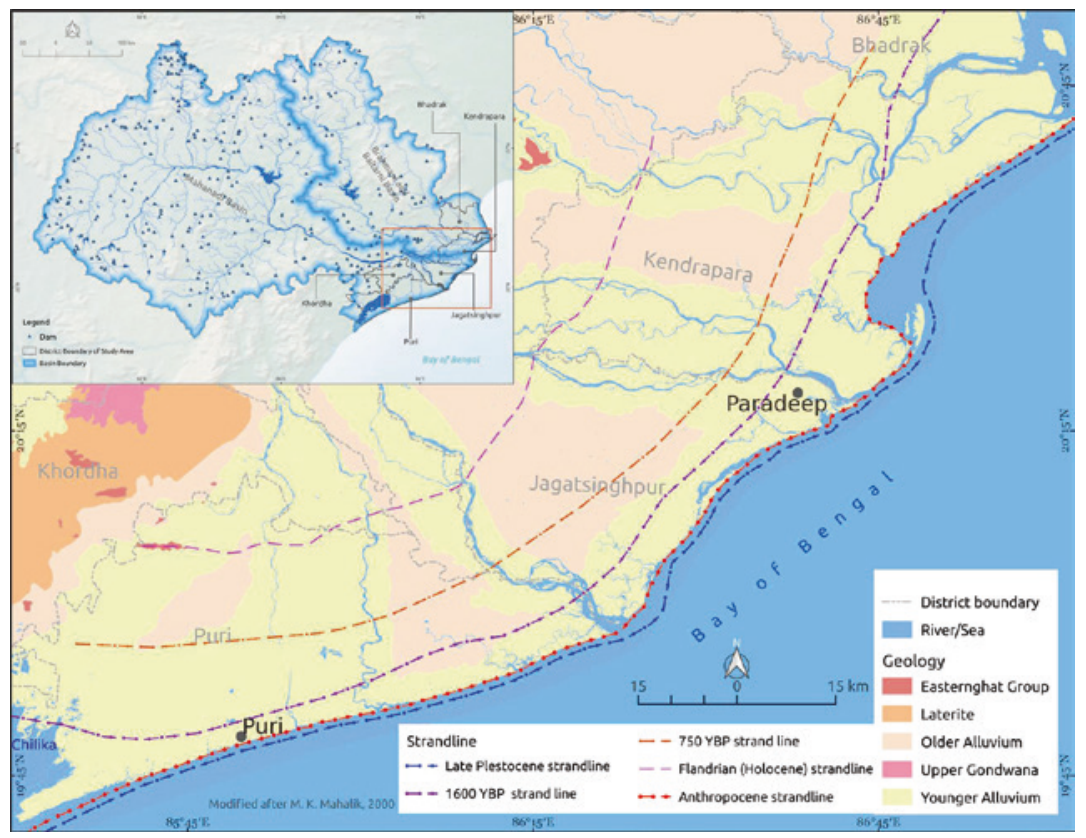

Fig. 5.3 Overview of the Mahanadi Delta and its upstream catchment illustrating the location of dams within the catchment 
and Baitarini rivers contribute water and sediments to the delta. The coastline of the delta is about $200 \mathrm{~km}$ long, extending from the Chilika lagoon in the south to the Dhamara River in the north. The luxuriant mangrove forests of Bhitarkanika, the nesting grounds for the Olive Ridley Turtle on the spits and sandy barrier islands of Gahirmatha and the rich biodiversity of the Chilika lagoon make the delta an important biodiversity hotspot. The delta apex lies near Cuttack, approximately 90 $\mathrm{km}$ inland from the coast (ibid.). The delta is fed by the $851 \mathrm{~km}$ long Mahanadi River, which at $142,589 \mathrm{~km}^{2}$ drains one of the largest basins of the east coast of India. The annual discharge of the Mahanadi River at the Naraj dam is $1545 \mathrm{~m}^{3} / \mathrm{s}$, but the delta experiences a highly variable seasonal flow regime with peak flows of up to $45,000 \mathrm{~m}^{3} / \mathrm{s}$ generated during the southwest monsoon period. The mean annual suspended load of $27.07 \mathrm{Mt}$ and bed load of $2.70 \mathrm{Mt}$ is therefore supplied to the delta mainly during the monsoon months (Ray 1988; Ray and Mohanti 1989).

Located within distances of 7-35 km of the coast, a series of three shore-parallel beach ridges indicate three paleo-stand lines, from which the past evolution of the delta can be established. Moving seaward, the ridges are dated between $5880 \pm 120 \mathrm{BP}$ and $4250 \pm 210 \mathrm{BP}, 1590 \pm$ 150 to $1220 \pm 180 \mathrm{BP}$ and $750 \pm 50 \mathrm{BP}$, respectively (Somanna et al. 2016). These dates suggest subaerial delta progradation of around $4 \mathrm{~m} /$ yr through much of the Holocene, increasing to $9 \mathrm{~m} / \mathrm{yr}$ after $\sim 1700 \mathrm{BP}$ until 1950.

Delta growth has declined significantly since the 1950s, particularly after the construction of the multi-purpose Hirakud Dam in 1957, which is located $300 \mathrm{~km}$ upstream (see Chapter 3). The construction of the Hirakud Dam across the Mahanadi River, along with the 60 other small and medium scale dams in the Brahmani-Baitarani river basin between 1975 and 2000 (WRIS 2014) has led to a significant loss of annual fluvial sediment supply of up to $67 \%$ in the Mahanadi and around $75 \%$ in the Brahmani Rivers (Gupta et al. 2012). This trend is expected to continue with a projected 234 additional small and medium scale dams and barrages expected to be built in the catchment over the next 40 years (Fig. 5.3). The loss of sediment supply has already been reflected in the diminished aggradation and increased 
erosion along a large stretch of the delta (Kumar et al. 2016), albeit with a roughly 20-year lag in the response at the shoreline following dam closure (Fig. 5.4). Specifically, historical movements of the coastline have been analysed with the End Point Rate (EPR) and Linear Regression Rate (LRR) methods and the Digital Shoreline Assessment System (DSAS) tool (Mukhopadhyay et al. 2018) of the United States Geological Survey (Fig. 5.4). These analyses indicate that, from 1990 to 2010, the shoreline receded around 90 meters near the tourist city of Puri in the south west of the delta to as much as 235 meters at Satabhaya in the north. Significant accretion (210 meters) is seen only around the port city of Paradeep where port construction and guide walls have intercepted sediment transport along the coast (Fig. 5.4). At present, $65 \%$ of the shoreline is under moderate to severe erosion, with increasing intensity from the south to north (ibid.). Forecasts of the position of the future coastline for the years 2020, 2035 and 2050 have also been undertaken, in which it was estimated that about 26 coastal

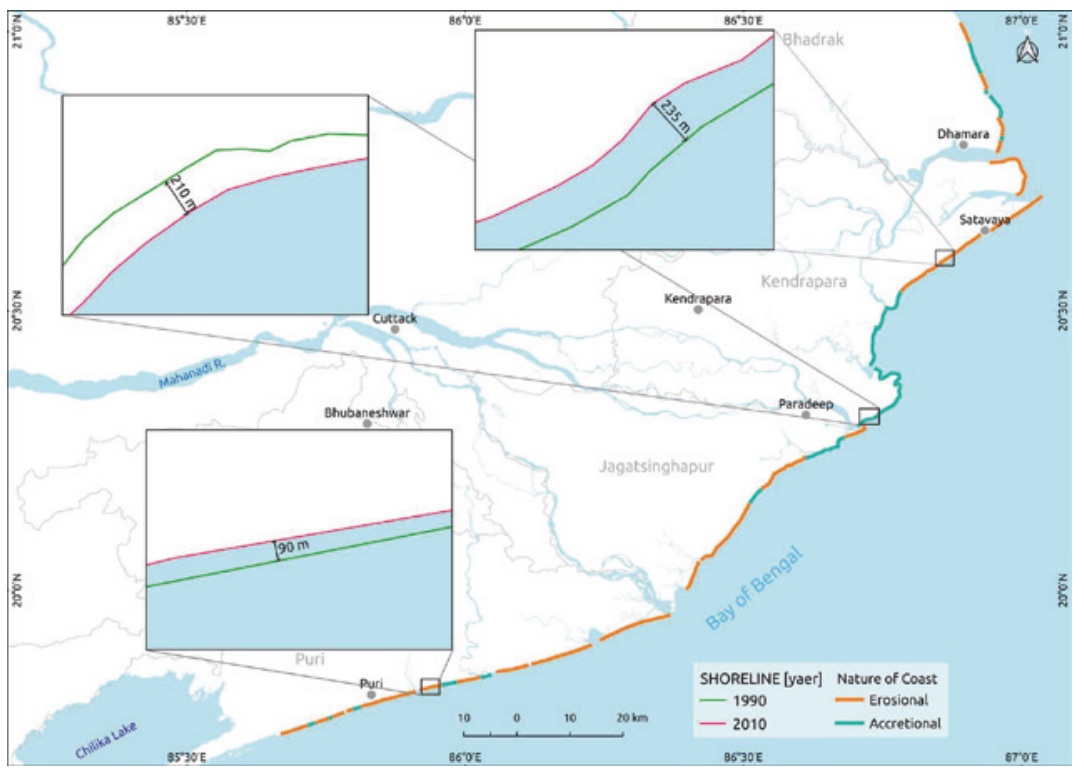

Fig. 5.4 Historical shoreline changes along the Mahanadi Delta coastal front 
mouzas (small administrative blocks) out of 87 (each with an average population density of $\left.>400 / \mathrm{km}^{2}\right)$ would be under the threat of displacement by the year 2050 (Mukhopadhyay et al. 2018).

Changes in the progradation rate of the delta shoreline may also be driven by variations in the rate of relative sea-level change. As computed from the tide level data at Paradeep station (Source PSMSL [www.psmsl. org], 1966-2014), the relative sea-level rise seems to have accelerated in the period from 1995 to 2015 to reach a value of $8 \mathrm{~mm} / \mathrm{yr}$. At the same time, the coastal districts of the delta have witnessed a rapid growth of population and increased water withdrawal, small and medium scale irrigation projects that use both surface and ground water, deforestation of mangroves and the growth of ports, industries and urbanisation, e.g., the growth of Bhubaneswar. This means that the number of people, and the economic value of assets, exposed to flooding has increased even as relative sea-level rise is accelerating. Indeed, as with all low-lying deltas, flooding is not an unusual phenomenon on the Mahanadi Delta. Before construction of the Hirakud Dam, the delta experienced 27 devastating river floods in the 88 years between 1869 and 1957, with only nine such floods subsequently (to 2011) (Beura 2015). However, the situation in the delta is further complicated by the construction of over 200 small to medium dams in the upper catchment, mostly for irrigation. In case of high rainfall events, these low capacity dams cannot store much runoff and are opened to prevent breaching. Similarly, the Hirakud Dam, with a significantly reduced (28\%) water storage capacity due to heavy siltation with time, has to pass excess water downstream. For any flow discharge over $20,000 \mathrm{~m}^{3} / \mathrm{s}$, large areas of the delta are thus now exposed to river flooding, despite the dams upstream. With an increasing trend of high rainfall events (Mohapatra and Mohanty 2005), the frequency of severe riverine flooding has actually increased in the delta (Jana and Bhattacharya 2013). Eight high-intensity flooding events during the period 2001-2015 can be spatially differentiated over 41 separate events across the delta (Ghosh et al. 2019), with severe attendant impacts on the lives and livelihoods of the deltaic communities. Thus, technological interventions on the rivers and the delta have a potential to further exacerbate the frequency and extent of flooding coupled with erosion and inundation along the coast in the Anthropocene. 


\section{The Volta Delta}

The Volta Delta (Fig. 5.5) falls within the Keta sedimentary basin, which is one of several fault-controlled sedimentary basins in West Africa (Jørgensen and Banoeng-Yakubo 2001). The Keta basin is characterised by soft, highly compressible organic or inorganic clays overlaying fine sand, a point which is relevant to understanding contemporary controls on deltaic subsidence rates. A significant portion of the delta landscape is also characterised by the Keta Lagoon complex, the Songor lagoon, a number of creeks along the coast, extensive marsh areas, as well as extensive mangroves (see Chapter 4 and Appeaning Addo et al. 2018). The Volta River basin $\left(390,000 \mathrm{~km}^{2}\right)$ has three main tributaries namely the White Volta, the Black Volta and the Oti River (Ibrahim et al. 2015) that drain a predominantly sandstone catchment that also includes a wide variety of lithologic terranes; the Volta being one of the main sources of sediment supply to the Gulf of Guinea (Goussard and Ducrocq 2014). The yearly sediment transport before the Akosombo Dam construction was about 71 million $\mathrm{m}^{3}$, which has now reduced by about $90 \%$ following construction of the Akosombo Dam in 1965 (Boateng et al. 2012).

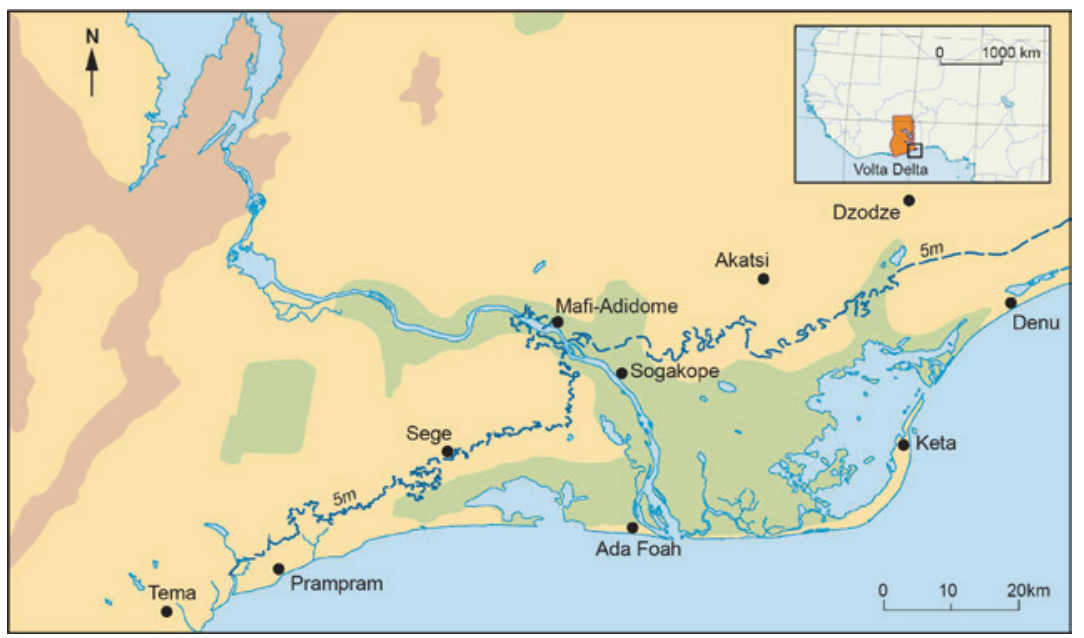

Fig. 5.5 Area of the Volta Delta in Ghana showing major settlements and the $5 \mathrm{~m}$ contour 
The Volta River historically carried large quantities of sediment, including coarse-grained sand, to the sea and this sediment was deposited at the river mouth, forming the modern delta (Nairn et al. 1999). The surplus of sediments has built the delta lobe off the original bedrock shoreline. The coarser sand fractions are transported by the littoral drift towards beach ridges to the east of the river mouth, while the finer mud and silt fractions, input by the Volta river, have formed a plume on the shore face east of the river mouth and on the shelf (Anthony and Blivi 1999). The Volta River has a single outlet channel to the sea at Ada with a low $(1 \mathrm{~m})$ tidal influence (cf. the Ganges-BrahmaputraMeghna delta discussed in Sect. 5.3.1). The estuary is associated with a large spit that is highly dynamic. This large spit is as a result of the direct outgrowth of a natural change in the location of the mouth of the river (Anthony et al. 2016). An eastward shift, of about $12 \mathrm{~km}$, in the point at which the river entered the sea has occurred since 1974 (Barry et al. 2005). The Volta Delta has features both of (river) sediment and wave domination; the sediment domination is expressed by the seaward protrusion of the delta off of the bed-rock, rather than a land-sided in-carving (Roest 2018). Carbon dating of bore-hole soil samples shows a multi-layered deltaic soil system, with peat layers dated at 5000-7000 years BP (Streif 1983). This indicates that the current perimeter of the delta has remained in its approximate position for an extended period of time (Roest 2018). However, this is expected to change into the future as sediment discharge from the Volta River has greatly reduced and pressures on the delta system are increasing.

Major hydroelectric dams constructed on the Volta River in 1965 at Akosombo and Kpong (downstream of Aksombo) in 1982 are now significantly influencing the delta sediment supply and morphology. The river's discharge varied between $1000 \mathrm{~m}^{3} / \mathrm{s}$ in the dry season and over $6000 \mathrm{~m}^{3} / \mathrm{s}$ in the wet season before the construction of the Akosombo Dam (Anthony et al. 2016). Runoff before dam construction was about $87.5 \mathrm{~mm} / \mathrm{yr}$, compared to the post-dam period value of $73.5 \mathrm{~mm} / \mathrm{yr}$ (Oguntunde et al. 2006). Since the construction of the dam, there are no longer any pronounced peaks in flow discharge and the sediment transport is reduced to only $10 \%$ of the original transport rate (Bollen et al. 2011; Boateng et al. 2012). The reduced sediment supply 
to the delta system has affected the evolution of the delta (Appeaning Addo et al. 2018), shifting from a sediment-dominated towards a more wave-dominated delta (Roest 2018). As a result of the control of water discharge, flooding patterns in the delta have also changed and the annual flood-flushing of the river mouth ceased (Anthony et al. 2016). The flood plains now rely on irrigation and there is a reduced water supply for farming (Corcoran et al. 2007; Ofori-Danson et al. 2016).

Changes in the sediment flow into the delta has resulted in a significant recession of the shoreline and increased coastal flooding along the shoreline especially during energetic swell events (Allersma and Tilmans 1993). Coastal erosion in the Volta Delta was first reported in 1929, but is posited to have existed since at least the 1860s, particularly in Keta (Nairn et al. 1999). Ly (1980) estimated that the shoreline in Keta was eroding at a rate between 4 and $8 \mathrm{~m} / \mathrm{yr}$, while Bollen et al. (2011) reported that the shoreline in Totope-Ada is receding at a rate of about $6 \mathrm{~m} / \mathrm{yr}$. Kumapley (1989) estimated that a strip of coastal land about $1 \mathrm{~km}$ wide has been lost to erosion since 1880s. The damaging impact of erosion and flooding has resulted in the construction of engineering structures in more developed areas over the last 30 years, mainly comprising groynes and revetments, to manage the erosion and flooding in hot spot areas (Boateng 2009). Although these methods have provided localised solutions to these problems, they have also transferred the erosion and flooding problems to the down-drift coast (Angnuureng et al. 2013). Hence, in the Volta Delta, the dominant current process is erosion and sediment starvation on the open coast. Looking to the future, flooding and submergence becomes more likely as sea levels rise and subsidence continues.

\subsection{Synthesis and Prospects}

To conclude this overview of the geomorphological factors driving relative sea-level rise in three representative deltas, it is appropriate to consider the prospects in terms of how: (i) projected environmental changes may affect future sediment loads to each delta, and; (ii) management interventions that could be adopted to help promote 
sediment deposition to mitigate against sea-level rise and subsidence. Regarding the former issue, in their recent paper Dunn et al. (2018) employed a catchment model, WBMsed, to project changes in fluvial sediment delivery to each of these deltas across the twenty-first century. They also developed a series of model scenarios to represent potential future pathways of environmental change encompassing climate change, socio-economic change and reservoir construction through to the end of the twenty-first century. Specifically, the climate data used were derived from the Met Office Hadley Centre Global Environment Model version 2-Earth System (HasGEM2-ES) at 0.5 degree resolution using Representative Concentration Pathways (RCP) 2.6, 4.5, 6.0 and 8.5 from Jones et al. (2011). Reservoir data for each catchment were taken from the future dam database of Zarfl et al. (2015), which includes information on hydropower dams with over $1 \mathrm{MW}$ generating capacity, both planned and under construction. Finally, the socio-economic data employed (Gross National Product [GNP] and population changes) were taken from Murakami and Yamagata (2016) to reflect the Shared Socio-economic Pathways (SSP) 1, 2 and 3. This combination of four climate and three socio-economic pathways led to a total of 12 future scenarios of change, with the reservoir construction scenarios in each case being embedded in the timelines for each future scenario (see Dunn et al. 2018).

The results indicate declining sediment loads during the remainder of this century, for the GBM and Mahanadi Deltas. Specifically, for the GBM Delta sediment loads at the end of the twenty-first century are projected to decline substantially: to 79-92 Mt/a (depending on scenario), compared to a contemporary value of $\sim 500 \mathrm{Mt} / \mathrm{a}$ (Rahman et al. 2018). This decline is caused primarily by projected socio-economic changes in the catchment (specifically substantial increases in projected GNP which are associated with improved land management practices and lower sediment yields), with new reservoir construction being a secondary factor. At the same time, future climate change is projected to have a slight positive impact $(-15 \%$ increase $)$ on future fluvial sediment loads, partially offsetting the direct anthropogenic impacts. For the Mahanadi Delta, there is much greater variability in projected future sediment loads across the 12 investigated scenarios and the overall 
future relative decline in sediment load is less than for the GBM, but there is again a significant projected decline in overall fluvial sediment delivery (between -5 and $25 \mathrm{Mt} / \mathrm{a}$ by 2100 ) compared to the recent past (40 Mt/a). In contrast, the Volta's trajectory is very different to that of the GBM and Mahanadi Deltas. In the case of the Volta, future changes in sediment load to the delta are negligible (changing from $\sim 0.3 \mathrm{Mt} / \mathrm{a}$ to between 0.2 and $0.4 \mathrm{Mt} / \mathrm{a}$ depending on scenario by 2100). This reflects that the main anthropogenic impact has already occurred in one event following the construction of the Akosombo Dam in 1965, when almost all the pre-disturbance sediment supply ceased. This means that the Volta Delta already has a near zero fluvial sediment supply and there is no significant potential to restore it, assuming the continued presence of the Akosombo Dam.

In conclusion, and with regard to the role of fluvial sediment supply modulating relative sea-level rise in deltas, the global prognosis is not good, with an expectation of continued decline in sediment supply. Deltas such as the Volta and the Nile which have essentially lost their entire sediment supply due to major dams are not expected to see any positive changes. It should be noted that this prognosis does not consider climate-induced sea-level rise, which further exacerbates the situation. Moreover, it is also apparent that this prognosis is similar to the overview provided by Syvitski et al. (2009), meaning that in the ten years since that review little has changed in terms of the understanding of key anthropogenic drivers influencing relative sea-level change in deltas. Hence the prognosis for Anthropocene deltas remains one of relative loss of elevation, submergence and decline, or increasing use of engineering approaches. However, other management interventions could be successful. Ironically, if the world's deltas are seriously threatened as a result of the major human imprint on these fragile environments, then thoughtful, targeted, human agency could still offer opportunities to reverse, or at least slow, the worst impacts. For example, the Mississippi Delta has seen a failure of sediment supply and fundamental change to its hydrology and huge areas of land have been, and will continue to be, lost (Meade and Moody 2009). Nevertheless, active restoration of the Mississippi's delta is now the subject of serious investigation including major water diversions and hopes of increasing the sediment supply from 
the Mississippi River (e.g., Nittrouer et al. 2012). However, as losses continue it must be questioned if these efforts will reverse losses or simply slow or maybe stabilise the situation. As a contrast, the Netherlands has similar trends to other deltas, but the risk of flooding is nonetheless very low due to an intense engineering effort of both soft (on the open coast) and hard (along the rivers) measures. New governance measures have also been implemented in the form of a Delta Plan and a Delta Commission which is promoting a more adaptive and strategic approach to delta management. However, residual risk cannot be entirely eliminated and failure would be catastrophic with growing consequences over time as sea levels rise and the land sinks. Importantly, it has recently been argued that the Dutch approach may result in deltas becoming trapped in a 'dual lock-in' (Seijger et al. 2018) in which both engineering technology and institutional interests act as constraints to moving into the (arguably) more sustainable direction afforded by restoration efforts.

Looking more widely, the question is can the Dutch and/or Mississippi approaches be explored together in many deltas where there are large populations and sediment loads? Engineering can be considered as a means to promote human and economic safety and controlled flooding and sedimentation to raise land levels or build new land. What is possible needs to be assessed at the delta level and on a delta by delta basis, suggesting that the local Delta Plans (e.g., in Bangladesh for the GBM and in Viet Nam for the Mekong Delta) that are emerging need to be replicated more widely to address local circumstances and needs. These suggest the need for major human involvement in the development of populated deltas in the coming decades and longer. Tidal River Management (defined as controlled flooding and sedimentation within polders) is already practiced locally in the GBM Delta (Angamuthu et al. 2018), but the scale of application needs to increase dramatically to keep pace with relative sea-level rise. In the Mekong, flooding is now recognised as being necessary to bring sediments and nutrients to rice agriculture, which might offer a strategy for future management (Chapman and Darby 2016). More remote and relatively unpopulated deltas, such as those in the Arctic, might be left to their own devices, but even here, indirect human influence in the catchment is likely to increase and needs to be carefully considered. 


\section{References}

Allersma, E., \& Tilmans, W. M. K. (1993). Coastal conditions in West Africa-A review. Ocean \& Coastal Management, 19(3), 199-240. https:// doi.org/10.1016/0964-5691(93)90043-X.

Allison, M. A. (1998). Historical changes in the Ganges-Brahmaputra Delta front. Journal of Coastal Research, 14(4), 1269-1275.

Allison, M. A., Khan, S. R., Goodbred, S. L., \& Kuehl, S. A. (2003). Stratigraphic evolution of the late Holocene Ganges-Brahmaputra lower delta plain. Sedimentary Geology, 155(3), 317-342. https://doi.org/10.1016/ S0037-0738(02)00185-9.

Angamuthu, B., Darby, S. E., \& Nicholls, R. J. (2018). Impacts of natural and human drivers on the multi-decadal morphological evolution of tidally-influenced deltas. Proceedings of the Royal Society A: Mathematical, Physical and Engineering Science, 474, 2219. https://doi.org/10.1098/rspa.2018.0396.

Angnuureng, B. D., Appeaning Addo, K., \& Wiafe, G. (2013). Impact of sea defense structures on downdrift coasts: The case of Keta in Ghana. Academia Journal of Environmental Science, 1(6), 104-121. http://dx.doi. org/10.15413/ajes.2013.0102.

Anthony, E. J., Almar, R., \& Aagaard, T. (2016). Recent shoreline changes in the Volta River Delta, West Africa: The roles of natural processes and human impacts. African Journal of Aquatic Science, 41(1), 81-87. https:// doi.org/10.2989/16085914.2015.1115751.

Anthony, E. J., \& Blivi, A. B. (1999). Morphosedimentary evolution of a delta-sourced, drift-aligned sand barrier-lagoon complex, western Bight of Benin. Marine Geology, 158(1), 161-176. https://doi.org/10.1016/ S0025-3227(98)00170-4.

Anthony, E. J., Brunier, G., Besset, M., Goichot, M., Dussouillez, P., \& Nguyen, V. L. (2015). Linking rapid erosion of the Mekong River Delta to human activities. Scientific Reports, 5, 14745. http://dx.doi.org/10.1038/ srep14745.

Appeaning Addo, K., Nicholls, R. J., Codjoe, S. N. A., \& Abu, M. (2018). A biophysical and socioeconomic review of the Volta Delta, Ghana. Journal of Coastal Research, 34(5), 1216-1226. http://dx.doi.org/10.2112/ JCOASTRES-D-17-00129.1.

Barry, B., Obuobie, E., Andreini, M., Andah, W., \& Pluquet, M. (2005). The Volta River basin: Comparative study of river basin development and management (Report) (p. 51). Colombo, Sri Lanka: International Water 
Management Institute (IWMI) and Comprehensive Assessment of Water Management in Agriclture (CAWMA). http://www.iwmi.cgiar.org/assessment/files_new/research_projects/river_basin_development_and_management/VoltaRiverBasin_Boubacar.pdf. Last accessed 14 August 2018.

Beura, D. (2015). Floods in Mahanadi River, Odisha: Its causes and management. International Journal of Engineering and Applied Sciences, 2(2), 51-55.

Boateng, I. (2009, May 3-8). Development of integrated shoreline management planning: A case study of Keta. Federation of International Surveyors Working Week 2009. Eilat, Israel. https://www.fig.net/resources/proceedings/fig_proceedings/fig2009/papers/ts04e/ts04e_boateng_3463.pdf. Last accessed 14 August 2018.

Boateng, I., Bray, M., \& Hooke, J. (2012). Estimating the fluvial sediment input to the coastal sediment budget: A case study of Ghana. Geomorphology, 138(1), 100-110. https://doi.org/10.1016/j.geomorph. 2011.08.028.

Bollen, M., Trouw, K., Lerouge, F., Gruwez, V., Bolle, A., Hoffman, B., et al. (2011). Design of a coastal protection scheme for Ada at the Volta River mouth (Ghana). In Proceedings of 32nd Conference on Coastal Engineering, 2010. Shanghai, China: International Conference on Coastal Engineering (ICCE). http://dx.doi.org/10.9753/icce.v32.management.36.

Brown, S., \& Nicholls, R. (2015). Subsidence and human influences in mega deltas: The case of the Ganges-Brahmaputra-Meghna. Science of the Total Environment, 527, 362-374. https://doi.org/10.1016/j. scitotenv.2015.04.124.

Cazenave, A., \& Remy, F. (2011). Sea level and climate: Measurements and causes of changes. Wiley Interdisciplinary Reviews: Climate Change, 2, 647662. https://doi.org/10.1002/wcc.139.

Chapman, A., \& Darby, S. (2016). Evaluating sustainable adaptation strategies for vulnerable mega-deltas using system dynamics modelling: Rice agriculture in the Mekong Delta's An Giang Province, Vietnam. Science of the Total Environment, 559, 326-338. https://doi.org/10.1016/j. scitotenv.2016.02.162.

Corcoran, E., Ravilious, C., \& Skuja, M. (2007). Mangroves of western and central Africa. UNEP-WCMC Biodiversity Series 26. Cambridge, UK: UNEPRegional Seas Programme. https:/www.unep-wcmc.org/resources-and-data/ mangroves-of-western-and-central-africa. Last accessed 14 August 2018.

Crutzen, P. J., \& Stoermer, E. F. (2000). The 'Anthropocene'. The International Geosphere-Biosphere Programme (IGBP) Global Change Newsletter, 41, pp. 17-18. 
Darby, S. E., Dunn, F. E., Nicholls, R. J., Rahman, M., \& Riddy, L. (2015). A first look at the influence of anthropogenic climate change on the future delivery of fluvial sediment to the Ganges-Brahmaputra-Meghna Delta. Environmental Science: Processes \& Impacts, 17(9), 1587-1600. https://doi. org/10.1039/C5EM00252D.

Darby, S. E., Hackney, C. R., Leyland, J., Kummu, M., Lauri, H., Parsons, D. R., et al. (2016). Fluvial sediment supply to a mega-delta reduced by shifting tropical-cyclone activity. Nature, 539(7628), 276. http://dx.doi. org/10.1038/nature19809.

Dunn, F. E., Nicholls, R. J., Darby, S. E., Cohen, S., Zarfl, C., \& Fekete, B. M. (2018). Projections of historical and 21 st century fluvial sediment delivery to the Ganges-Brahmaputra-Meghna, Mahanadi, and Volta Deltas. Science of the Total Environment, 642, 105-116. https://doi.org/10.1016/j. scitotenv.2018.06.006.

Erban, L. E., Gorelick, S. M., \& Zebker, H. A. (2014). Groundwater extraction, land subsidence, and sea-level rise in the Mekong Delta, Vietnam. Environmental Research Letters, 9(8), 084010.

Ericson, J. P., Vörösmarty, C. J., Dingman, S. L., Ward, L. G., \& Meybeck, M. (2006). Effective sea-level rise and deltas: Causes of change and human dimension implications. Global and Planetary Change, 50(1-2), 63-82. https://doi.org/10.1016/j.gloplacha.2005.07.004.

Ghosh, A., Das, S., Ghosh, T., \& Hazra, S. (2019). Risk of extreme events in delta environments: A case study of the Mahanadi Delta. Science of the Total Environment, 664, 713-723.

Giosan, L., Syvitksi, J. P. M., Constantinescu, S., \& Day, J. (2014). Climate change: Protect the world's deltas. Nature, 516, 31-33. https://doi. org/10.1038/516031a.

Goussard, J. J., \& Ducrocq, M. (2014). West African coastal area: Challenges and outlook. In S. Diop, J.-P. Barusseau, \& C. Descamps (Eds.), The land/ ocean interactions in the coastal zone of West and Central Africa (pp. 9-21). Heidelberg, Germany: Springer.

Gupta, H., Kao, S.-J., \& Dai, M. (2012). The role of mega dams in reducing sediment fluxes: A case study of large Asian rivers. Journal of Hydrology, 464-465, 447-458. https://doi.org/10.1016/j.jhydrol.2012.07.038.

Hazra, S., Dey, S., \& Ghosh, A. K. (2016). Review of Odisha state adaptation policies, Mahanadi Delta. Deltas, vulnerability and climate change: Migration and adaptation (DECCMA) (Working Paper). Southampton, UK: DECCMA Consortium. https:/generic.wordpress.soton.ac.uk/deccma/ resources/working-papers/. Last accessed 6 August 2018. 
Ibrahim, B., Wisser, D., Barry, B., Fowe, T., \& Aduna, A. (2015). Hydrological predictions for small ungauged watersheds in the Sudanian zone of the Volta basin in West Africa. Journal of Hydrology: Regional Studies, 4, 386-397. https://doi.org/10.1016/j.ejrh.2015.07.007.

Jana, A., \& Bhattacharya, A. K. (2013). Assessment of coastal erosion vulnerability around Midnapur-Balasore Coast, Eastern India using integrated remote sensing and GIS techniques. Journal of the Indian Society of Remote Sensing, 41(3), 675-686. https://doi.org/10.1007/s12524-012-0251-2.

Jones, C. D., Hughes, J. K., Bellouin, N., Hardiman, S. C., Jones, G. S., Knight, J., et al. (2011). The HadGEM2-ES implementation of CMIP5 centennial simulations. Geoscientific Model Development, 4(3), 543-570. http://dx.doi.org/10.5194/gmd-4-543-2011.

Jørgensen, N. O., \& Banoeng-Yakubo, B. K. (2001). Environmental isotopes $(18 \mathrm{O}, 2 \mathrm{H}$, and $87 \mathrm{Sr} / 86 \mathrm{Sr})$ as a tool in groundwater investigations in the Keta basin, Ghana. Hydrogeology Journal, 9(2), 190-201. https://doi. org/10.1007/s100400000122.

Kumapley, N. K. (1989). The geology and geotechnology of the Keta basin with particular reference to coastal protection. In W. J. M. van der Linden, S. A. P. L. Cloetingh, J. P. K. Kaasschieter, W. J. E. van de Graaff, J. Vandenberghe, \& J. A. M. van der Gun (Eds.), Coastal lowlands: Geology and geotechnology (pp. 311-320). Dordrecht, The Netherlands: Springer.

Kumar, K. V., \& Bhattacharya, A. (2003). Geological evolution of Mahanadi Delta, Orissa using high resolution satellite data. Current Science, 85(10), 1410-1412.

Kumar, R., Kaushik, M., Kumar, S., Ambastha, K., Sircar, I., Patnaik, P., et al. (2016). Integrating landscape dimensions in disaster risk reduction: A cluster planning approach. In F. G. Renaud, K. Sudmeier-Rieux, M. Estrella \& U. Nehren (Eds.), Ecosystem-based disaster risk reduction and adaptation in practice (pp. 271-291). Cham, Switzerland: Springer. http://dx.doi. org/10.1007/978-3-319-43633-3_12.

Ly, C. K. (1980). The role of the Akosombo Dam on the Volta River in causing coastal erosion in central and eastern Ghana (West Africa). Marine Geology, 37(3), 323-332. https://doi.org/10.1016/0025-3227(80)90108-5.

Meade, R. H., \& Moody, J. A. (2009). Causes for the decline of suspended-sediment discharge in the Mississippi River system, 1940-2007. Hydrological Processes, 24(1), 35-49. https://doi.org/10.1002/hyp.7477.

Milliman, J. D., \& Syvitski, J. P. M. (1992). Geomorphic/tectonic control of sediment discharge to the ocean: The importance of small mountainous rivers. Journal of Geology, 100, 525-544. 
Milliman, J. D., Yun-Shan, Q., Mei-E, R., \& Saito, Y. (1987). Man's influence on the erosion and transport of sediment by Asian rivers: The Yellow River (Huanghe) example. The Journal of Geology, 95(6), 751-762. https://doi. org/10.1086/629175.

Minderhoud, P. S. J., Erkens, G., Pham, V. H., Bui, V. T., Erban, L., Kooi, H., et al. (2017). Impacts of 25 years of groundwater extraction on subsidence in the Mekong Delta, Vietnam. Environmental Research Letters, 12(6), 064006 http://dx.doi.org/10.1088/1748-9326/aa7146.

Mohapatra, M., \& Mohanty, U. C. (2005). Some characteristics of very heavy rainfall over Orissa during summer monsoon season. Journal of Earth System Science, 114, 17-36.

Morgan, J. P., \& McIntire, W. G. (1959). Quaternary geology of the Bengal basin, East Pakistan and India. Geological Society of America Bulletin, 70(3), 319-342.

Mukhopadhyay, A., Ghosh, P., Chanda, A., Ghosh, A., Ghosh, S., Das, S., et al. (2018). Threats to coastal communities of Mahanadi Delta due to imminent consequences of erosion-Present and near future. Science of the Total Environment, 637-638, 717-729. http://dx.doi.org/10.1016/j. scitotenv.2018.05.076.

Murakami, D., \& Yamagata, Y. (2016). Estimation of gridded population and GDP scenarios with spatially explicit statistical downscaling. ArXiv, 1610.09041. https://arxiv.org/abs/1610.09041.

Nairn, R. B., MacIntosh, K. J., Hayes, M. O., Nai, G., Anthonio, S. L., \& Valley, W. S. (1999, June 22-26). Coastal erosion at Keta Lagoon, Ghana: Large scale solution to a large scale problem. In Proceedings of the 26th Conference on Coastal Engineering 1998. Copenhagen, Denmark: American Society of Civil Engineers. http://dx.doi.org/10.1061/9780784404119.242. Nicholls, R. J., Hutton, C. W., Lázár, A. N., Allan, A., Adger, W. N., Adams, $\mathrm{H}$., et al. (2016). Integrated assessment of social and environmental sustainability dynamics in the Ganges-Brahmaputra-Meghna Delta, Bangladesh. Estuarine and Coastal Shelf Science, 183, 370-381. http://dx.doi. org/10.1016/j.ecss.2016.08.017.

Nittrouer, J. A., Best, J. L., Brantley, C., Cash, R. W., Czapiga, M., Kumar, P., et al. (2012). Mitigating land loss in coastal Louisiana by controlled diversion of Mississippi River sand. Nature Geoscience, 5(8), 534. http://dx.doi. org/10.1038/ngeo 1525 .

Ofori-Danson, B., Lawson, E. T., Ayivor, J. S., \& Kanlisi, R. (2016). Sustainable livelihood adaptation in dam-affected Volta Delta, Ghana: Lessons of NGO support. Journal of Sustainable Development, 9(3), 1913-9071. http://dx.doi. org/10.5539/jsd.v9n3p248. 
Oguntunde, P. G., Friesen, J., van de Giesen, N., \& Savenije, H. H. G. (2006). Hydroclimatology of the Volta River basin in West Africa: Trends and variability from 1901 to 2002. Physics and Chemistry of the Earth, Parts $A / B / C, 31(18), 1180-1188$. https://doi.org/10.1016/j.pce.2006.02.062.

Pethick, J., \& Orford, J. D. (2013). Rapid rise in effective sea-level in southwest Bangladesh: Its causes and contemporary rates. Global and Planetary Change, 111, 237-245. https://doi.org/10.1016/j.gloplacha.2013.09.019.

Rahman, M., Dustegir, M., Karim, R., Haque, A., Nicholls, R. J., Darby, S. E., et al. (2018). Recent sediment flux to the Ganges-Brahmaputra-Meghna Delta system. Science of the Total Environment, 643, 1054-1064. http://dx. doi.org/10.1016/j.scitotenv.2018.06.147.

Ray, S. B. (1988). Sedimentological and geochemical studies on the Mahanadi River estuary, east coast of India (Unpublished $\mathrm{PhD}$ thesis). Utkal University, Bhubaneswar, India.

Ray, S. B., \& Mohanti, M. (1989). Sedimentary processes in the Mahanadi River estuary, east coast of India. In Workshop on coastal processes and coastal quaternaries of Eastern India (pp. 28-29). Calcutta, India: Geological Survey of India, Eastern Region.

Roest, L. W. M. (2018). The coastal system of the Volta Delta, Ghana: Strategies and opportunities for development. Delft, The Netherlands: TU Delft Delta Infrastructures and Mobility Initiative (DIMI). https://repository.tudelft. nl/islandora/object/uuid:6d859f80-e434-407e-b0bc-41f574ff8b6f. Last accessed 22 October 2018.

Seijger, C., Ellen, G. J., Janssen, S., Verheijen, E., \& Erkens, G. (2018). Sinking deltas: Trapped in a dual lock-in of technology and institutions. Prometheus, 1-21. http://dx.doi.org/10.1080/08109028.2018.1504867.

Smajgl, A., Toan, T. Q., Nhan, D. K., Ward, J., Trung, N. H., Tri, L. Q., et al. (2015). Responding to rising sea levels in the Mekong Delta. Nature Climate Change, 5, 167-174. http://dx.doi.org/10.1038/nclimate2469.

Somanna, K., Somasekhara Reddy, T., \& Sambasiva Rao, M. (2016). Geomorphology and evolution of the modern Mahanadi Delta using remote sensing data. International Journal of Science and Research, 5(2), 1329-1335.

Streif, H. (1983). Die Holozäne entwicklung und Geomorphologie der Küstenzone von Ghana. In D. Kelletat (Ed.), Essener Symposium zur Küstenforschung, Essner Geographische Arbeiten Band 6 (pp. 1-27). Paderborn, Germany: Schöningh.

Syvitski, J. P. M., \& Kettner, A. (2011). Sediment flux and the Anthropocene. Philosophical Transactions of the Royal Society A: Mathematical, Physical and Engineering Sciences, 369(1938), 957-975. 
Syvitski, J. P. M., Kettner, A. J., Overeem, I., Hutton, E. W. H., Hannon, M. T., Brakenridge, G. R., et al. (2009). Sinking deltas due to human activities. Nature Geoscience, 2(10), 681-686. http://dx.doi.org/10.1038/ngeo629.

Tessler, Z. D., Vörösmarty, C. J., Grossberg, M., Gladkova, I., Aizenman, H., Syvitski, J., et al. (2015). Profiling risk and sustainability in coastal deltas of the world. Science, 349(6248), 638-643. http://dx.doi.org/10.1126/science. aab3574.

Tessler, Z. D., Vörösmarty, C. J., Overeem, I., \& Syvitski, J. P. M. (2018). A model of water and sediment balance as determinants of relative sea level rise in contemporary and future deltas. Geomorphology, 305, 209-220. https://doi.org/10.1016/j.geomorph.2017.09.040.

Wilson, C. A., \& Goodbred, S. L. (2015). Construction and maintenance of the Ganges-Brahmaputra-Meghna Delta: Linking process, morphology, and stratigraphy. Annual Review of Marine Science, 7(1), 67-88. https://doi. org/10.1146/annurev-marine-010213-135032.

WRIS. (2014). Dams in Mahanadi. Water Resource Information System of India. http://india-wris.nrsc.gov.in/wrpinfo/index.php?title=Dams_in_Mahanadi. Last accessed 25 October 2018.

Zarfl, C., Lumsdon, A. E., Berlekamp, J., Tydecks, L., \& Tockner, K. (2015). A global boom in hydropower dam construction. Aquatic Sciences, 77(1), 161-170. https://doi.org/10.1007/s00027-014-0377-0.

Open Access This chapter is licensed under the terms of the Creative Commons Attribution 4.0 International License (http://creativecommons. org/licenses/by/4.0/), which permits use, sharing, adaptation, distribution and reproduction in any medium or format, as long as you give appropriate credit to the original author(s) and the source, provide a link to the Creative Commons license and indicate if changes were made.

The images or other third party material in this chapter are included in the chapter's Creative Commons license, unless indicated otherwise in a credit line to the material. If material is not included in the chapter's Creative Commons license and your intended use is not permitted by statutory regulation or exceeds the permitted use, you will need to obtain permission directly from the copyright holder.

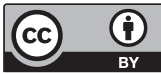

